\title{
POLICY IMPLEMENTATION OF A LINE LEARNING SYSTEM TO PREVENT THE SPREAD OF COVID-19
}

\author{
Mike Fatiha Eka Riswanda ${ }^{1}$, Agus Machfud Fauzi ${ }^{2}$ \\ ${ }^{1-2}$ Faculty of Social Sciences and Law, Surabaya State University \\ mike.18014@mhs.unesa.ac.id ${ }^{1}$, agusmfauzi@unesa.ac.id ${ }^{2}$
}

\begin{abstract}
The positive online learning system policy is enforced for all levels of school, from kindergarten, elementary, junior high, high school to tertiary level. This policy was enforced due to the Covid-19 pandemic, for this reason an online learning system or distance learning was implemented as an effort to prevent the spread of Covid-19. The online learning system policy is deemed the right policy to be implemented in the face of the current pandemic because teachers and students do not meet face to face directly. Based on this background, the objectives of this study are 1) understanding and explaining the application of the online learning system policy in Mts Ketegan Sidoarjo, 2) analyzing the motives for implementing the online learning system policy at Mts Ketegan Sidoarjo. The method used in this study is a qualitative method, because to explain the research was carried out in depth. The theory used in this research is Schutz's theory of social motives. Schuzt introduced two motive terms, namely the "cause" motive (because of motive) and the "goal" motive (in order to motive), this theory can be used to reveal the real motive behind the implementation of the online system policy in Mts Ketegan Sidoarjo. The results of this study indicate that the policies are implemented in accordance with applicable regulations because they are given the purpose of the policy itself, namely to prevent the spread of Covid-19.
\end{abstract}

Keywords: action motive; education policy; pandemic

\begin{abstract}
Abstrak : Kebijakan sistem pembelajaran daring positif diberlakukan untuk seluruh jenjang sekolah mulai dari TK, SD, SMP, SMA hingga ke jenjang perguruan tinggi. Kebijakan tersebut diberlakukan akibat adanya pandemi Covid-19, untuk itu sistem pembelajaran daring atau pembelajaran jarak jauh diterapkan sebagai upaya untuk mencegah penyebaran Covid-19. Kebijakan sistem pembelajaran daring dirasa kebijakan yang tepat untuk diterapkan dalam menghadapi pandemi saat ini karena antara guru dengan murid tidak bertatap muka secara langsung. Berdasarkan latar belakang tersebut yang menjadi tujuan dari penelitian ini yaitu 1)memahami dan menjelaskan penerapan kebijakan sistem pembelajaran daring yang ada di Mts Ketegan Sidoarjo, 2)menganalisis motif pelaksanaan kebijakan sistem pembelajaran daring yang di Mts Ketegan Sidoarjo. Metode yang digunakan dalam penelitian ini yaitu metode kualitatif, karena untuk menjelaskan maka penelitian dilakukan secara mendalam. Teori yang digunakan dalam penelitian ini yaitu teori motif sosial dari Schutz. Schuzt memperkenalkan dua istilah motif yaitu motif "sebab" (because of motive) dan motif "tujuan" (in order to motive), teori tersebut dapat digunakan untuk mengungkap motif yang sebenarnya dibalik pelaksanaan kebijakan sistem daring yang ada di Mts Ketegan Sidoarjo. Hasil penelitian ini menunjukkan bahwa kebijakan diterapkan tidak sesuai dengan ketentuan yang berlaku karena mengingat dari tujuan kebijakan itu sendiri yaitu untuk mencegah penyebaran Covid-19.
\end{abstract}

Kata Kunci: motif tindakan, kebijakan pendidikan, pandemi

\section{INTRODUCTION}

The Covid-19 virus has been declared a pandemic by the World Health Organization (WHO) since March 11, 2020 (Sudarsana, 2020). The covid-19 pandemic has not only impacted the health sector, but all sectors including the education sector have also felt the impact of the pandemic. Based on a decree issued by the National Disaster Management Agency (BNPB) 
regarding the determination of an emergency period due to the corona virus, the Ministry of Education and Culture (Kemendikbud) issued a Circular from the Minister of Cultural Education 36962 / MPK.A / HK / 2020 dated 17 March 2020 concerning learning online and working from home in order to prevent the spread of the Covid-19 virus (Argaheni, 2020). Given the main priority of the government, namely prioritizing the safety and health of students, educators, families, and the general public.

In the education sector, online learning is implemented as a form of Work From Home (WFH). Online learning policies have been implemented in all schools at all levels of education starting from kindergarten to college. This policy is considered the right policy to be implemented in a pandemic like this, because online learning reduces the occurrence of direct face-to-face interactions between educators and students. The online learning system is implemented as an effort to prevent the spread of the Covid-19 virus so as not to increase the number of positive Covid numbers.

There are several previous studies that discuss educational policies during a pandemic. Learning online as a whole is carried out using applications in the form of Vclass, meet, zoom, Whatsapp, telegram, google classroom, youtube, facebook, and even messenger. Educators more often use two applications, namely WhatsApp and Google Classroom because it is considered the most practical and has a minimum quota when compared to other applications. Learning takes place smoothly but it is felt by most educators and students if the communication runs not smoothly which results in the material being difficult to understand (Rosali, 2020).

In (Widiyono, 2020) it is explained that the majority of students prefer to use the WhatsApp application during online learning. However, online learning makes learning less effective because of the many obstacles such as network constraints, making it difficult for students to understand the material. In this study, it was also explained that the effective lecture system during pandei was online and offline which were carried out alternately while still paying attention to health protocols. Students prefer offline or face-to-face learning, but they accept the reality of online learning as a consequence of WFH (Mustakim, 2020). Online learning is considered to make learning ineffective, and many students experience physical complaints such as eye fatigue and headaches caused by staring at cellphones or laptops too often. In addition, cooperation between teachers and parents is needed. There are parents who work so they cannot accompany their children while studying using cellphones or online. So it is hoped that parents of students will provide a special schedule to accompany them to learn like other students (Sudarsana, 2020).

Unlike the previous research, in (Sourial, Longo, Vedel, \& Schuster, 2018) explains that online learning makes students more independent because it puts more emphasis on student center. They are more courageous to express their opinions and ideas. Supported by the government which has also provided several platforms that students can use to learn.

Of the five studies above, there are different views. Several studies stated that online learning resulted in ineffective teaching and learning activities. Students have difficulty understanding the material presented by the teacher. In addition, online learning found many obstacles such as network constraints, there were students who were not good at operating their cellphones for learning activities, and many students who experienced physical complaints such as tired eyes and headaches due to staring too often at the cellphone or laptop screen. However, there is one study that has a different view, namely saying that online learning can make students more independent because the learning is centered on the student itself, thus training students to be courageous in conveying their ideas or opinions.

The five studies above have something in common, namely that they both discuss what platforms are used during online learning activities and discuss the advantages and disadvantages of learning online. However, none of the five studies have discussed other motives for implementing online learning policies carried out by the school. Therefore this study seeks to show the novelty of online learning system policies seen from the other side, namely the motives for implementing online learning policies. 


\section{METHODS}

This research uses qualitative methods with the hope of being able to produce in-depth descriptions of speech, writing, and observable behavior of certain individuals, groups, communities or organizations in a particular context. Qualitative research aims to gain a general understanding of social reality from the informants' point of view. This understanding is obtained after analyzing the data obtained.

The approach used in this study is a phenomenological approach with the perspective of Alfred Schutz's theory of social action motives. Schutz divides social action into two concepts, namely the concept of because motive (motive cause) and in order to motive (motive aim). The motive for the cause of the action carried out by the perpetrator is motivated by past events or based on the personal experience of the perpetrator of the action himself. The objective motive, namely the action taken by the actor (actor) has expectations that involve intent, plan, anticipation, and prediction (Suhaidah et al., 2013).

The research subjects used a purposive sampling technique in which the research subjects were selected by the researcher based on the research objectives. The subjects of this research were educators including extracurricular coaches at Mts Ketegan . Data collection techniques are carried out in two ways, namely through primary data and secondary data. Primary data were obtained directly from informants using the interview method. Secondary data were obtained from literature reviews including journals and online media that were related to the research title. The data analysis technique starts from the reduction stage, namely summarizing the data that has been obtained in the field, then presenting the data. The presentation of data in qualitative research is carried out in the form of descriptions or in the form of narrative text. The last stage is drawing conclusions, conclusions can be used to answer the problem formulation. The formulation of the problem in this study is how to implement the online learning policy at Mts Ketegan as an effort to prevent the spread of Covid-19?

\section{RESULTS AND DISCUSSION}

\section{Application of the online learning system at Mts Ketegan}

During a pandemic all crowd-generating activities are suspended. One of them is teaching and learning activities. The decision made by the Ministry of Education and Culture is that learning is carried out online or online (in a network). All levels of education from kindergarten to tertiary institutions apply the policy, including one of the junior high schools in Sidoarjo, namely Mts Ketegan. Mts Ketegan has implemented an online learning system policy since the issuance of the Ministry of Education and Culture's decision regarding the learning process during the pandemic. The school applies online learning to prevent the spread of covid19. Therefore teaching and learning activities between students and students are carried out virtually, without face to face directly.

Online learning is not fully implemented in Mts Ketegan. In these schools, they still carry out teaching and learning activities offline, by coming directly to the school. Offline learning is not carried out for 6 full days, but offline learning is carried out 2 face-to-face meetings in one week. The face-to-face meetings which are held 2 times a week are not held simultaneously, but are held in turns starting from grade VII to grade IX. For example, class VII on Tuesday and Thursday, class VIII on Monday and Friday and class IX Wednesday and Saturday. Teaching and learning activities at Mts Ketegan during the pandemic were slightly different from before during the pandemic. Students go to school wearing casual clothes provided that they are neat and polite, students do not wear school uniforms. This provision is a policy issued by the school. Subjects are taught according to the day the student enters school. Apart from these two days the learning was carried out online. Online learning at Mts Ketegan uses several platforms, namely google classroom, Edmodo, WhatsApp, YouTube and Facebook. 
The implementation of the learning policy in Mts Ketegan has differences with other schools. Based on previous research, most schools carry out online learning in full, by utilizing several applications, both Chat applications and special learning applications. Although online learning has advantages and disadvantages, they still carry out the policies set by the government. However, what happened in Mts Ketegan online learning was not carried out in full. The school still implements face-to-face learning, as well as extracurricular activities and intra-school activities.

\section{Extracurricular offline}

Overall online learning has caused anxiety both on the part of students, parents, and teachers. Students feel online learning is more difficult than learning that is done in person at school. The teacher only gave the material not accompanied by an explanation to the students. Each material is always inserted with a task that must be done by the student. This is what makes students nervous because of the many assignments given by the teacher. The parents of the students also shared their concerns during their children's schooling online. Almost all parents complained about the amount of expenditure used to buy data packages, because most students access the internet using cellular services. Only a small proportion of students use the WiFi network. Even though the government has reduced the quota assistance, the assistance is mostly intended for learning applications while the quota for accessing the internet is less than the quota for applications. This is why students often buy data packages. From the teacher's side said that online learning has its own challenges, namely, the teacher creates new innovations for the learning model that will be given to their students. In addition, online learning has many obstacles, such as weak internet networks, students who do not understand how to use learning applications, and constraints in delivering instructions from teachers that are not well received by students.

Mts Ketegan not only enforced offline learning during the pandemic, but extracurricular activities were still ongoing. The extracurricular activities are carried out offline. Students who take part in extracurricular activities continue to carry out these activities as usual even though their conditions are Work From Home (WFH). Extracurricular activities at Mt s Ketegan that were still running at the time of WFH were volleyball extracurricular activities, paskibraka and Pagar Nusa (pencak silat).

Until now, online learning is still being implemented, however extracurricular activities and intra-school activities such as the Intra School Student Organization (OSIS) run offline. Every time there is a student council activity meeting is carried out offline, with student council members coming directly to the school. Based on the results of an interview conducted by the researcher with one of the student council members, activity meetings during this new term were held with quite frequent intensity. Meeting or a working meeting activities are always carried onffline or face to face, although k egiatan learning is done through online.

\section{Because of Motive implementation}

Because of motive or cause motive relates to a person's reasons for taking an action as an attempt to create situations and conditions that are expected in the future (Iskandar \& Jacky, 2015). In simple terms, the cause motive is the reason behind a person in carrying out a certain action. In this study, there is a cause motive behind the subject in deciding extracurricular activities to be carried out offline during the pandemic, namely because there is a competition or competition that is followed. Therefore, extracurricular activities are still carried out, not online but directly meeting each other and face to face. More face-to-face meetings will be held as race day approaches. However, the competition which was followed by extracurricular activities was held virtually. So as not to cause a crowd that invites many people to gather in the same place.

The decision for extracurricular activities to be carried out offline is a decision made by the supervisor of the extracurricular activity, but the supervisor cannot carry out the decision without permission from the school. So before implementing the offline extracurricular policy, 
the extra coach must first submit a permit application letter to the school, namely the principal. The school gives permission for extracurricular activity policies that are carried out offline. This action was carried out as a form of effort to increase achievement and make the school proud. Extracurricular activities are carried out offline so that the coach can directly train and monitor the abilities of his students. If extracurricular activities are carried out online, it will be difficult for supervision and teaching, especially as a post-curricular extracurricular activity, which prioritizes cohesiveness in a team, which requires in-person meetings. Likewise with pencak silat and volleyball extracurricular activities that cannot be carried out online or virtually.

\section{In order to motivate the offline extracurricular implementation}

In order to motive or goal motive is a view of the factors that cause a person to take certain actions, or in other words, the goals that someone who takes certain actions want to achieve (Iskandar \& Jacky, 2015). In this research, what is discussed is about the goals to be achieved by the school as well as extracurricular coaches from extracurricular activities carried out offline. The aim is to increase school achievement in non-academic fields as well as to raise the good name of the school. In addition, participating in competitions can add to the experience for students who take extracurricular activities and to find out the extent of the abilities of these students. So that students who are considered by the extracurricular coaches are capable of participating in the competition, these students are included in the competition. To achieve this goal it is balanced with extra training. The training will be done more often as the competition day approaches. At Mts Ketegan, if previously training or extracurricular activities were carried out once a week, at the time of the competition, the training was carried out twice a week.

Extracurricular activities offline during the pandemic at Mts Ketegan, said the extracurricular coach if in implementation they still adhere to health protocols. Such as keeping your distance, washing your hands before and after finishing the exercise using running water. Even though they have goals to be achieved, the school and extracurricular coaches still adhere to health protocols, in order to prevent the spread of covid-19.

\section{CONCLUSIONS}

Based on the research results, it can be concluded that the online learning policy is not fully implemented in Mts Ketegan. It can be seen if the school continues to carry out offline learning during the pandemic. Not only teaching and learning activities, extracurricular activities and intra-school activities are still running as usual, namely being carried out offline even though these activities still comply with health protocols.

\section{REFFERENCES}

Argaheni, NB (2020). Systematic Review: The Impact of Online Lectures During the COVID19 Pandemic on Indonesian Students. PLACENTUM: Health Scientific Journal and Its Applications , 8 (2), 99. https://doi.org/10.20961/placentum.v8i2.43008

Iskandar, D., \& Jacky, M. (2015). Phenomenology study of motives for members of the 804 Student Regiment Unit of the State University of Surabaya. Journal of Social Sciences, State University of Surabaya , 3 (1), 1-12.

Mustakim, M. (2020). The Effectiveness of Online Learning Using Online Media During the Covid-19 Pandemic in Mathematics Subjects. Al asma: Journal of Islamic Education , 2 (1), 1. https://doi.org/10.24252/asma.v2i1.13646

Rosali, ES (2020). Online Learning Activities During the Covid -19 Pandemic In. Geography Science Education Journal (GEOSEE), 1(1), 21-30. Retrieved from 
https://www.researchgate.net/publication/340917125_Kendala_Pelaksana_Pembelajaran_ Jarak_Jauh_PJJ_dalam_Masa_Pandemi/stats

Sourial, N., Longo, C., Vedel, I., \& Schuster, T. (2018). Online to draw causal claims from nonrandomized studies of primary care interventions. Family Practice, 35 (5), 639643. https://doi.org/10.1093/fampra/cmy005

Sudarsana, IK (2020). COVID-19 EDUCATION PERSPECTIVE (K. Aria Prima Dewi PF, ed.). Our Writing Foundation.

Suhaidah, D., Studi, P., Nursing, I., Medicine, F., Science, DAN, Islam, U., \& Syarif, N. (2013). Thesis Submitted to Meet the Requirements for Obtaining a Bachelor's Degree in Nursing (S.Kep) .

Widiyono, A. (2020). The Effectiveness of Online Lectures for PGSD Students During the Covid Pandemic 19. Journal of Education , 8 (2), 169-177. https://doi.org/10.36232/pend Pendidikan.v8i2.458 